\title{
The Arab World and the Language of Politics
}

\author{
Abdullah Qabani \\ English Language Institute (ELI), King Abdulaziz University (KAU) \\ Jeddah, Saudi Arabia \\ E-mail: baqabani@kau.edu.sa
}

Received: January 14, 2022 Accepted: February 11, 2022 Published: February 28, 2022

doi:10.5296/ijl.v14i1.19623

URL: https://doi.org/10.5296/ijl.v14i1.19623

\begin{abstract}
Language society and politics are terms, which are interchangeably important. Those three terms are linked in a way that is beyond separation or argument when it comes to analyzing discourse in general and political discourse in particular. Through language, society can deliver politics and impose beliefs and ideologies. The relationship between Arabs in general and politics has been a source of questions for decades due to many reasons. These reasons vary between social and historic reasons. This study aims to discuss and track how Arab writers and scholars looked at politics in their writings and how they perceived its importance and role starting with the early Islamic era and ending with our current days. It has been found that there is an apparent and close relationship between politics and religion. Further, it has been noticed that the political discourse delivered by Arab leaders has not received proper attention in terms of its effect on the different Arabic societies and the different political events that took place throughout the post-colonialism era.
\end{abstract}

Keywords: Arab Spring, Politics, Arabs, Egypt, Uprising, Revolution

\section{Introduction}

The relationship between Arabs in general and politics has been a source of questions for decades due to many reasons. These reasons vary between social and historic reasons. Most of the countries in the Arab world are considered fairly new countries, given that most of them were established inside their current boarders or got their independence after world war one or even world war two. Even after years and decades of their establishment or independence many of these countries were ruled by the same political parties or political elite. For example Egypt was under the rule of military elite since 1952 and saw a civilian president only once in 2012 for less than a year. Libya is another country that was ruled by the famous colonel Gaddafi for more than 42 years until his ruling was ended on the hands of the Libyan rebels in 2011. The reason why we see that the ruling of these elite last longer in 
the Arab world than any other place in the world has been discussed in recent research. The first reason as argued in research is not because that Arab societies lack the ability to deal with politics, but because the political, usually military, elite succeeded for decades in convincing the people that they are the most able and capable of ruling and taking care of the interests of the people (Qabani, 2017). The elite depended heavily on playing with the emotions of the people (Qabani, 2021). Further, the elite identified themselves in certain ways that helped in prolonging their time as rulers and as head of states (Qabani, 2021). However, during Arab Spring things changed and what happened during Aab Spring stunned and surprised commentators and critics as per (Haas, 2018) and (Vysotsky, 2014) to mention some. The political elite could not stand in the face of the swarming protests because they kept on using the same controlling techniques and did not change the way they identified themselves to the people or to the media as per (Qabani, 2021).

The second reason is that Arab societies are patriarchic societies (Hisham Sharabi, 1992). Arab societies look at the president or the head of state as a father and as a symbol that has to be obeyed and respected. As could be seen in the study of Qabani (2017) all of the presidents their speeches were studies played the card of the betrayed father and expressed their sorrow that they were betrayed by their own sons. However, expression of sorrow and pain by these presidents did not succeed as for example in the case of Mubarak of Egypt.

It is suggested that after giving his last speech, which was given on the 10th February 2011, $64.4 \%$ of 3000 people felt positive about Mubarak stepping down (Hearst, 2011). This big number of pro-stepping down of Mubarak suggests a change in the way Egyptians think about politics and the authority of the father to use the term of (Hisham Sharabi, 1992). So, what are the background to all of this? How Arabs looked at politics and wrote about it? Have there been changes in the way Arabs wrote about politics and dealt with it in different periods? These questions and many other will be looked at throughout this review.

\section{Language Politics and Society}

Language society and politics are terms, which are interchangeably important. Those three terms are linked in a way that is beyond separation or argument when it comes to analyzing discourse in general and political discourse in particular. Through language, society can deliver politics and impose beliefs and ideologies. However, the way language is identified and looked at in a society could alter the way politics is looked at and practiced or even analyzed academically. The connection between language and society or social life has been the concern and the main theme of research of many sociological and linguistic theorists. The number of theorists who have had theoretical perspectives on the relation between language and social life is too abundant to be covered extensively and properly. However, it is important to indicate the work of (Goffman, 1981), (Labov, 1972), (H. Sacks \& Jefferson, 1992), (Crystal \& Davy, 1988), (Longacre, 1976), (Gumperz, 2009), (Schegloff, 1972), (Levinson, 1979), (Hymes, 1972) and (Biber, 1994).

language is a network of systems and interrelated sets of options that are set to make meaning. The Hallydian school of thought influences this definition, when it comes to language and language use. Halliday sees that language could only or primarily be seen and identified in 
the process of socialization. This school of thought argues that language use and language study cannot be proceeded with or conducted apart from the social structure in which language is produced and apart from the context the text or language was produced in (Eggins, 2004). So, in order for researchers or language analysists to understand, or alter understanding, the different meanings of a production of language, they need to understand first the surroundings and conditions that contributed to the production of this piece of language and understand why it was produced the way it was produced.

It could be seen from the discussion that there is a mutual relationship between language and society and that societies have got certain templates, which they use to exchange meaning and achieve goals depending on the cultural background of the society, each culture and society has their own templates and exchanging registers of talk and write, which they follow to communicate. By understanding those templates and categorizing them it is more likely for anybody to know how societies deal with language and how they employ language to play certain roles. However, where is politics in all of this?

It is suggested that people tend to disagree on the way politics is embedded into the social life and how a social interaction could be described as political. In other words people tend to describe the relationship between politics and social life as one of a conflict and sometimes cynical, so politics is something and social life is something else. What government and "states" do is "political" and what others (civil society) outside the institution of government do, including all kinds of interactions, is "non-political" or "non- influential". So, the supporters of this view or nature of politics defines it merely as the art of government or the state centered view of politics (Davis \& Go, 2009). However, this view or opinion about politics proved shortcomings in accordance with some other theorists when looking at politics. There are non-political individuals and entities that influence the political process such as civic associations, schools and capital market individuals. Those non- political entities play a role in the making of the policies in today's world and could press towards political matters that concern the society in the first place not the political elite and their definition of politics a definition the famous philosopher and poet Paul Valery lined profoundly as follows, "Politics is the art of preventing people from taking part in affairs which properly concern them" (Valéry, 1943). The same view of politics, furthermore, argues that even if there was a revolution of any kind on the ruling regime in any given society the same regime which have ruled in the past will prevail and rise to power again and rule over as they are the group or the elite that are destined to rule in that society because of certain social classifications and a critical climate that pushes toward such class division (Marcuse, 2002). It could be inferred so far that politics is an interaction of a somehow non-mutual nature. It happens and takes the fully interactive nature within political groups dominantly not the other "non-political classes.

On the other hand there is another view to politics. It is argued that politics is a positive activity that all citizens, who are all free and equal, have the right to participate in publicly for the good of the society and this action will give and cover life with meaning and affirm the distinctiveness of every and each individual (Arendt, 1998). So, politics and political action are social activities that take and maintain their tools from the society to the society, yet with different levels of authority and involvement (Tischler, 2010). In order for politics to 
flourish and be effective and unique society or social structure with tools such as language is needed to fulfil the meaning and definition of politics.

Politics in general is, as viewed and dealt with in different studies, a social interaction that is affected by culture and hold purpose in its tools. When people in different levels of authority and power interact within a political social system they need language to interact and reach a desired ideological influence. Though, a clear total distinction between political language and other ways of social interaction is not attainable, since there tend to be a disagreement on what characteristics make texts or speeches political and what evade them from being political production of language. Moreover, there is even a disagreement on the theoretical categories and methods of analysis of political discourse (Fairclough \& Fairclough, 2012).

By adopting the view of politics as a social interaction, studying political interaction within any society is more likely to accomplish three things. First of all, it is assumed that elucidation of the study of society and culture will be assisted. Language cannot be studied as if it was a foreign element to the social structure which produced it and to which it was contributed (Fairclough \& Fairclough, 2012). So, studying language production as constructed in a society especially political discourse, which participate different actions, actors and decisions, will indeed tell a lot about the society and the hierarchy of power for example.

Second of all, studying the political production of language within a society is a fruitful and meaty ground to study ideology. It is suggested that ideology is the link between thought and the real social world (Eagleton, 2014). When studying ideology as constructed in the language production of any society, how ideas related to real material conditions will be shown by disassembling them and placing them within other terms, and resolving their problems and conflicts so that they are turned into, " apparently natural, immutable universal ones" (Eagleton, 2014). It is suggested that mixing culture with linguistics is like looking through a glass or a lens. When that glass is correctly focused the true shape of many of the forces that are within will appear and the inscrutable nature of things will fade away (Whorf, 1956). By culturally understanding why communicative language was produced the way it was produced in a certain context a great deal of dispute, clash and judgements that are based on language will be invisible and bodiless thought.

Third and last of all, understanding the ways in which political rhetoric functions in the society could tell a lot about the existence of active citizenry (D. Sacks, Murray, \& Brody, 2009). According to the understanding of the Greeks to the notion of rhetoric, states, especially democratic states, depends on citizens of the state to make critical influential decisions throughout the life of their community, not only at special times of elections for example (D. Sacks et al., 2009). For the free citizens in democratic states to be able to make critical informed decisions that might affect the whole society or community, they need critical understanding of the language and its techniques to do so. However, it is not the only factor that could contribute to the process of the decision making. There are other factors that could contribute to the process, but language is one of the first and one of the most important factors. 
A critical understanding of language does not mean that all members of any society should be highly educated to be able to express and receive language critically. It is assumed that even people who have never studied, for example linguistics, before might be skilled at deconstructing the utterances of those in power and by using knowledge and background gained from their life experiences. The last assumption could be seen clearly within Arab societies, where leaders could stay in power for decades and tend to give speeches regularly in every occasion, which allows people to sometimes fully deconstruct the rhetorical language use of those leaders. The deconstruction of rhetorical language use and language use in general of Arab leaders does not stop at the people who deconstruct it, but they tend to teach their children what they have discovered and what they have deconstructed by experiences, so their children would not trust leaders and what they say. Those last points need to be addressed by research to be holistically, empirically and applicably proven; unfortunately they are out of the reach of this paper.

Regardless of how people deal with or look at language production in general or rhetorical production of language in particular it is suggested that the demystification of the techniques that political leaders follow to express their rhetorical use of language is or can be of significance to citizens of any society for two reasons. First, the demystification will or could enable people of any society to more deeply give critique to the language use of those in power or anticipate what actions might really be enforced rather than the actions promised, uttered or made public. Second, the demystification of the language use to those citizens who are interested might help them in participating in the political activity themselves, especially in the societies that enjoy an environment that allows this freely as a democratic right.

It is argued in this section that there is a non-separable relationship between language society and politics. The relationship between those three elements is of a dependable nature and underneath those elements come other elements that make the relationship even stronger. The human being, who is a part of other humans in the society, use language politically in every situation of his life to accomplish things and the field of "politics" is one of those situations in which humans use language politically to achieve things, so no wonder why Aristotle called humans "political animals" (Kraut, 2002). We as human beings socialize this way, it is the natures of human talk and be polite "political" in order to achieve things and those things differ as people differ in what they do and what they want to accomplish.

\section{Arabs and Political Discourse}

Arabs started to study and document their language after foreignness or solecistic speech started to occur in their spoken language, especially after the spreading of Islam and the embracing of Islam by non-Arabs. The study of Arabic started as one discipline and with one aim which is to preserve the eloquent Arabic language especially the language of The Holy Quran, however, after studies of Arabic got deeper and got more sophisticated, other disciplines of studying Arabic started to emerge depending on how scholars think and what branch of studying Arabic they are interested in (Suleiman, Suleiman, Tripp, \& Clancy-Smith, 2004); and since the reasons of the emergence of the Arabic studies in general was the preservation of The Holy Quran and Arabic in general, it could be seen that most of those 
disciplines have emerged almost during the same period (Suleiman et al., 2004). It is suggested that disciplines such as the discipline of interpretation of The Holy Quran, the discipline of Prophetic Narrations, the discipline of jurisprudence, Linguistics, Syntax morphology, philosophy, Logic and semantics all appeared at almost the same time for the reasons mentioned before and scholars used to have knowledge in them all with varied levels of perfection depending, as mentioned, what they are really interested in (Suleiman et al., 2004).

To trace back and discuss the literature that could be described as political or could go under the description of political discourse, it is significant to understand first what is meant by political discourse and what counts as political discourse in the eyes of Arab scholars and their studies either in the current era or the past. To look at the topic from the very beginning Arabs used to communicate for the purposes of war, politics and social life events through prose and poetry. Poetry used to have the upper hand above all means of communications. It could be seen throughout the recorded history of Arabic and Islamic culture poets, who were imprisoned for the poetry they delivered in certain events and occasions (Falkoff, Miller, \& Dorfman, 2007). That rings a bell when it comes to today's ideas of freedom of speech and restrictions from governments on media and what should be said and what should not. However, at that time even though prose and poetry played a role in politics, they were never categorized as political. More light will be shed on how the political thought appeared in the Arabic-Islamic domain and what are the factors that paved the road to this appearance.

To find a certain point to start from, a term found in the Arabic literature will be presented and taken as a point of depart. This term is "the Sultanic Literatures". Even though there is a great debate among scholars on the boundaries and definition of the term "the Sultanic Literatures", however, for the sake of discussion and clarity some general aspects of the term will be given and then a definition will be reached. It is suggested that the term "the Sultanic Literatures" means and refer to the writings and the literature that appeared after the end of Caliphate period and the start of kingship period around 661 AD (Hawting, 2002). That literature was in general derived from the Persian literature. "The Sultanic Literature" described different aspects of the idea of kingship and the political life in general in the Islamic Empire (Esposito, 1998). What characterizes these writings is that they are based on the principle of advice to the rulers, on how to run and deal with their kingship; they contain huge number of advice on morals, etiquettes that the rules should follow in regard to himself and in regard to his servants and his attitude toward his enemies (Esposito, 1998). It is suggested that these writings depended in the formation of their arguments in regard to what makes ethical politics on three systems, which are the Persian, the Greek and the political Islamic law. It is suggested that these writings tried to compose one compound of these three referential systems in order to avoid any possible inconsistency or discrepancy, which makes it a unique blend that cannot be totally deemed to be a copy of one of the systems just referred to (Esposito, 1998).

Before going into describing these writings and showing their political characters and effect on the political life of their time, it should be noted here that up until this time this kind of literature did not receive a suitable attention in terms of discussion or research, which raises 
many question regarding the relationship between politicians and the publics in the Arab-Islamic world even in those early days. The suggested reasons behind such negligence were pertained to the nature of these writings and the nature of the ruling of that era, which was strict authoritarian. Some other explanation of such aversion pertain negligence to the claim that such writings or literature is away or does not express the real Islamic spirit (Esposito, 1998). However, the look, which all parties have in regard to this kind of writing or literature is irrelevant to what is the aim of this review of the Arabic studies in political discourse; a deep discussion is also deemed irrelevant.

It is almost agreed among scholars that "the Sultanic Literatures" give a practical view on what politics should look like, and by practical they meant how politics should be executed and practiced (Botcheesh, 2014). From a comprehensive look at these writings it could be concluded that by giving advice to the head of state, these writings aimed to empower authority of the state and tenacity of kingship. The just mentioned opinion on these writings is not haphazard it is manifested in the definitions of these writings which were coined by many scholars. All the definition were in a way or another implying the following when defining "the Sultanic Literatures", "Sultanic Literatures are political advices delivered to the head of state or the crown prince in order for him to be a successful ruler". Definitions in line with what just been mentioned can be found in the discussion of these writings in (Abbas, 1977), (Alqadi, 1981), (Badwi, 1954) and Asayed, 1984). The same scholars also assert that these writings are governed by the practical look to politics and that these writings were built and written for one purpose and that is to empower the country and head of state. One of the interesting things or claims about these writings or literature is that they were written using second person point of view to address the reader as if it was directly meant to the first man or the head of the state and no one else (Esposito, 1998). This claim will be tested shortly alongside discussion on the general structure of these writings and the political topics they tackle in general. Moreover, it is suggested that these writings were to a far extent similar in the way they enacted stages of discussion or advancement of discussion, starting from the title of the book, letter or covenant and ending with the conclusion (Esposito, 1998). The previous claim suggests that these writings formed a genre, which all writers followed when writing about this domain or register of literature. Mostly in all those writings the production starts with a blazing usually rhymed title to express that what in the book or literary production reflects the body of the book, letter or covenant (Qabani, 2017). Examples of some titles will be given below.

Example 1

\begin{tabular}{|l|l|}
\hline Title & $\begin{array}{l}\text { الثهب اللادعة في النياسة } \\
\text { Translation }\end{array}$ \\
\hline The illustrious \\
& $\begin{array}{l}\text { meteors in the } \\
\text { gainful politics. }\end{array}$ \\
\hline
\end{tabular}


Example 2

\begin{tabular}{|c|c|}
\hline Title & المنهج المسلوك في سباسة \\
\hline Translation & $\begin{array}{l}\text { The followed path } \\
\text { in kings politics }\end{array}$ \\
\hline
\end{tabular}

As can be seen the titles are structured to have a certain impact on the reader, which the writers wanted to be perceived. It is suggested that writers in this art usually re-mention the title in the preface of their books to highlight why did they pick this or that titles. Writers usually picked dazzling titles to show that certain books offer more wisdom in terms of politics to the king or caliph and that when walking on the path illustrated in the book the ruling or kingship of the ruler will get empowered and last longer. In the titles of some of these books writers referred to their writings as advisory and some others referred to them as "enlighten", which implies that this book will light the path of the ruler or the Sultan and show them the right path through the darkness and hardships of politics (Esposito, 1998). The list of political books that hold titles derived from rareness, brightness and other glazing features goes on and on when it comes to this kind of art at that era.

When it comes to the preface or introduction of these writings it is noticed that the introductory part is of great importance, as it usually contains information that help in understanding the goal of compiling such a book or letter. Moreover, it is noticed that when it comes to the structure of the preface, there are obligatory elements and optional elements, to use the terms of Hasan (2009), found in the different prefaces of different writers. The obligatory elements in these writings could be described as the elements that writers employ in their writings to show that their work is a moral political working guide and that the head of state is the first person meant of these writings. The optional elements usually revolve around what is in the mind of the writer and what he wants to achieve or mainly gives advice about in his book or letter to the head of state. For example in the book written by القلعي Alqalie under the title," Perfecting Presidency and Prioritizing politics", he states that his book is particularly about what should be used and what should not be used of ruling tactics. He further, states what tactics can be advantageous and what tactics can be disadvantageous (Ajjo, 1985).

As can be seen from the discussion so far the main topic in general for these writings is politics, however, when talking about politics people usually have different conceptions on what makes politics depending on their surrounding environment, so is it possible to reach a conclusion on how did they at that era perceived and conceptualized politics by looking at these writings? It could be noticed that almost all the writings referred to as "Sultanic Literature" have a technical and practical understanding of politics, they used to think of politics as something that could be learned and with certain rules, let them be moral, ethical or personal features, kingship and empowering of authority will be reached and prolonged and guarded till the time comes for the current ruler to step down in favor of the crown prince. To support what just been theorized, the technical and the practical understanding of politics could be seen for example by looking at the book written by 1300s under the title "The Signal in practicing Princeship", in which he states in the preface 
that, "these are thirty chapters, if the wise comprehended a chapter every day, the month would not end until he has comprehended an ample amount of wisdom and a prime branch of politics" (Ismael \& Almazidi, 2003). Another example could be found in a book written by - Alghzali under the title "The Minted Gold in Advising Kings", he directs speech to the head of state saying," when the sun has risen order a reader every Friday to read for you from this book so that you add to your knowledge," (Shamsudain, 1988). There are many other books and letters that look at politics from the same perspective and conceptualize politics into the same template. Moreover, the political writers of that era did not concern themselves with the issue of how did the country or the authority came into existence, its history or even its legitimacy, rather those writers totally restricted themselves in their writings to the means, techniques and the methods the head of state can utilize to expand his authority and increase its prestigious status (Esposito, 1998).

By looking at the political literature available of that era, which as suggested took the form of advice and formed a recognized genre among writers of that field, no hint or signal were recorded on how heads of state, kings or Caliphs benefited from these writings in terms of how to deal with the citizens or attend to international politics. The significance of knowing how these writings ended up or what purpose did they really serve rise when we know that some of those writings were written by direct orders from some Caliphs and heads of state of that era, which suggest either a form of consultation needed from the part of heads of state or for another reason only those who gave these orders knew about. One of the books that were written by direct orders from heads of state was a book written by إين الربييع Ibn-Alrabee around the 1200s under the title "The Demeanor of the King in Managing Kingdoms". In the preface and under the head of this the writer stated that he wrote this book because someone, whose orders are to be answered and obeyed, gave the order so that this book is to be compiled and taken care of (AL-Saud, 2010).

A very interesting point might deserve to be pondered upon here before moving on is the relationship between heads of state and writers of such literature. As could be seen from the above account so far that some of the books were written by direct orders from heads of state and some other books, which are the majority, were not. If a book appeared as a response to the order of heads of state then the reasons might be attributed to what heads of state wanted to do with the book as was the case with Malik-Shah I (1072 - 1092), who ordered writers to write about their opinion about his ruling and his running of the country to fix any flaw that might affect the country's superiority. The Sultan picked a book written by نظام الملك and Nizam al-Mulk under the title "The Biographies of Kings", which means that was the book that met what was in the mind of the Sultan. Even then the history did not mention what was the effect of that book on the ruling of the sultan or what happened after receiving the book form the author. However, if the writer composed the book on his own and then addressed the king or the head of state in its preface then the question of why should be raised here.

By looking at the writings of that era and from some of the examples mentioned here it could be seen that in the prefaces of those writings, either the ones that were written by a direct order of heads of state or the ones that did not, writers showed great enthusiasm and eagerness to deliver books and address them the one who has been chosen by God to 
represent him on earth or to the one ever since his ruling started the prosperity never left the country, even though, some of those writers in their books cautioned the publics from being a usual face in the gatherings heads of state hold. Why writers were so eager to be objects of adulation and in the same time as mentioned cautioned others from accompanying heads of state? Were they after some sort of accreditation as the writers of the kings for example? Were they after a social status and prestige, which usually comes with accompanying kings and head of states? The answer to those questions will remain unknown as history never mentioned why.

In the previous section the preface and some aspects related to the way Sultanic literature perceived politics were covered; in this section the body and the general topics of those political writings will be covered. By taking a look at fairly a small number of these writings available from the era covered, it could be noticed that these books formed a genre in the way they enacted writing. Different scholars from different disciplines usually followed a similar structure. The same applies to these writings in terms of the topics they covered. By looking at the table of contents of three books, it could be seen that there are three obligatory topics that all writers included in their books. These elements or topics are 1- how the Sultan should act and what virtues should he has 2- the employees of the Sultan or head of state 3- what preserve kingship in the country. Each one of these elements will be further discussed by looking at the following books; the book written by نظام الملك Nizam al-Mulk under the title "The Biographies of Kings", the book written by إين الربيع Ibn-Alrabee around the 1200s under the title "The Demeanor of the King in Managing Kingdoms" and the book written by - Almuradi around the 1300s under the title "The Signal in Reigning".

The first category that can be found in all of these books is the category of how should the head of state or the king act and what moral virtues should he has. This category was discussed in the three books under titles such as, "A chapter in speaking and silence", "A chapter in taming personality" and "A chapter in spending, generosity and saving". From the titles just mentioned it could be argued that all of them revolve around what virtues the politician should have and how to act.

The second category is the category under which the employees of the head of state and everything that is related to them is discussed. This category is discussed under titles like, " $\mathrm{A}$ chapter in counselors and how to know them", "A chapter in military people and what should be done for them" and 'A chapter in assistants and how to assign duties to them".

The third category, which is the category under which writers discuss and present what should the head of state pay attention to so that his ruling and his kingship last as strong and long as possible. Under this category topics such as how to run the fortune and the assets of the country, how to build the country in terms of infrastructure and cities design and judicial matters alongside some other topics are discussed. Writers also differ in how much attention they give each category. For example some writers give great attention to the issue of military power and its effects on the country and its superiority. Some other writers give great attention to the issue of justice and its effects on the people of the county and some others on the physical assets of the country and how to build and engineer the cities of the country. For 
example it could be seen in the book written by نظام الملك Nizam al-Mulk under the title "The Biographies of Kings" that he gives great attention to the category of the employees of the head of state, how to deal with them, how to punish them and how to choose them. However, it could be seen in the same book that the issue of building the country and designing did not attract a lot of attention. On another example it could be seen in the book written by الهرادي Almuradi around the 1300s under the title "The Signal in Reigning", that the writer gave a great attention to the category of how the head of state should act and what are the characteristics and virtues that are the best for the head of state to follow and train himself on maintaining. The same book gave fairly little attention to the category of employees of the state and how to deal with them when compared to the attention given to the category of characteristics of the head of state and the virtues he must follow.

As there are obligatory elements in all of these political books, there are optional elements that were present in some books but not others. For example, some books tend to be the only books that mentioned jails and how to run them and the living of inmates inside these jails, such as the book written by المالقي - Almaliqi around the 1300s under the title "The illustrious meteors in the gainful politics". In his twenty first chapter he dedicated his account to jails and what happen inside them and stories of some inmates. Such elements are not common among all political books, so that is why they are considered optional and discussed as unique characteristics of only some books.

From what have been presented so far it could be seen that all the writings in politics and the political life in Arabic at the early Islamic era took the form of advice to the head of state. The writings did not discuss the legitimacy of those political figures nor the governments or type of governance they were leading and the place of people in terms of power sharing at that era. Moreover, when taking a look at the way they understood politics it could be noticed that what those writers practiced was not politics and the advices they gave to the head of state was not meant to serve the people of the country in the first place but to serve politics as was understood at that time, which is how to expand authority and strengthen kingship. Before going on, a question might arise here, which is why politics to those scholars meant only serving the head of state and make sure that he stays strong and authoritative as long as he can? The answer might lie in the fact that the prevalent idea at that time was that the ruler must be obeyed and that the total submission to the ruler is a characteristic of a good Muslim, which raises many questions about the boundaries between religion and kingship. Furthermore, it is made so clear and direct in most of these writings that by following those advices, or let them be called conditions, the ruler will make political advancements regardless of what normal people think or believe.

\section{A More Recent Era}

The era that is going to be discussed here is the era of post-colonization or the era of kingdoms and republics. It is suggested that the topics of Arabic political speech of post-colonization era revolved around prosperity and independence (Gray, 2010). The political speech of that era did not try to look at the situation in hand or the political problems that were there in the era after independence. However, the political speech tried to look for a 
different reality, in a vague and indirect way, not to fix the current reality and build on it (Stephanous, 2012). It is suggested that another characteristic of the Arabic political speech is that it practices politics using topics that are irrelated to politics such as the relationship between the authority and the citizens and the issue of state and how should the society supports and protects it, (Meier, 1990). We can notice that the topics did not change much from the period discussed in the beginning of this paper. Topics such state is above all and that a long lasting state under the ruling of a symbol is the way to prosperity were common topics of the political speeches of that era. Without going deep into theorizing and describing this era; some studies that cover the start of this era up until the current days will be presented and discussed.

One of the first Arabic studies that provided an analysis of political speeches, was a study done by (Marzūq, 1966). In this study, which was published in Arabic as a book under the title, Political Oratory in Egypt from the British Occupation to the Declaration of Protectorate, the writer discussed the political oratory in Egypt in the years between 1882 and 1914. In this study the author studied the circumstances that affected and were the reasons behind the appearance of political oratory at that time. Moreover, he studied some of the public speeches given by some of those who are thought of as stars in the field of political speech giving till these days as Mustafa Kamel - مصطفى كامل, Mohammed Fareed - محد فريب and Abdullah Anadeem - عبد/له النديم.

The author used different tools and approaches to discuss his data. For example we can see that the author utilized historical tools to discuss the social and political circumstances that were the motives behind the speeches delivery.

The author did not only discuss the society and the political environment of his data, but he studied the "oratorical style" as well. It is meant by the "oratorical style" the characteristics that distinguished different orators from each other. He also studied and connected between the structure of the political speeches and between the contexts in which these speeches were given. The connection was in terms of what language was used, techniques of persuasion and techniques of leading and the effects of these techniques on the audience or the targeted audience and whether they were natives, young people or people of different social classes.

It could be inferred from the study of Marzūq (1966) that the author did not follow a certain theoretical methodology or approach to his study neither he discussed them literary. He followed different traditional rhetorical methods from the traditional studies of Arabic and Aristotelian rhetoric. In plain words his method toward political speeches could be described in order of steps as follows. The first step was identifying the context of the speech under discussion and why it has been delivered and the reaction of public or audience to it, a method which was taken from the ideas of Aristotle and the traditional Arabic work on rhetoric. The second step was to connect between the structure and kind of language used in the speech and the nature of audience and the context. The third step was the specification and discussion of the "oratorical style" of the speech giver and discussion about the role it played on the audience in terms of motivation.

It could be seen from the description of the methodology of this study that it is a study that 
took a great interest in the social political language in use. It further used tools, regardless of how well presented they are, specified for the purposes of studying language (communication) within a certain society and during certain events (context), to extract and identify effective "oratorical styles" that could work if used again under similar circumstances by others (linguistic rhetorical analysis).

One interesting thing about this study is that it admired the context and its effect on the political language use of that time and a great sum of that study was deeply and amply concentrated on the situation, environment and context of political speech and the circumstances behind the appearance, development and sometimes fading of the political oratory. Another thing, as readers go through this study, they get the feeling that it is a historical study. However, the historical account did not come at the expense of the other elements of the study such as the characteristics of the style of the orators.

There have been also many other Arabic studies that followed this study and discussed different topics and used different methodologies and approaches to answer the questions they raised. For example, the study published in 1981 by Marleen Nasr - مارلين نصر. The author studied the concept of nationalism from Jamal Abdunassir's - جمال عبد/لناصر point of view. The author approached the data by using the analysis of the semantic fields, an approach that grounds upon identifying the main concept in different texts and then identify the other concepts presented in the texts as either harmonious with the main concept or discordant with it (Nasr, 1981). All that happens in order to reach and decode the conceptual network of the text or texts under investigation. What distinguishes this study is that it was one of the first studies that investigated what were the conceptions of an Arab leader toward certain topics. In summary this study answered the question of why an Arab leader said that thing or acted that way. It is needless to say that the explanation was based on the context and the environment of the speeches.

Another example is a study published in 1990 by Abdulaleem Mohammed - عبد/العليم محمد. The aim of this study was roughly to answer two questions and these questions could be formed as what are the characteristics of Sadat's ideology? And what is the role of his political speech in forming and presenting that ideology? To approach these questions the author made use of the ideology criticism methodologies that Marxist literature had to offer, such as looking at the texts with the social and material conditions that made these texts in mind. By following such approaches the author was able to tackle and provide very interesting conclusions. The author claims that Sadat was so successful in expressing his ideology to the degree that majority of Egyptians strived to defend it even though some of these ideologies were going against their interests (Mohammed, 1990). The common feature between the three studies just discussed is that they were conducted and published after the passing away of all the political figures their speeches were studied. For example, the study conducted by Marleen Nasr - مارلين نصر about the speeches of Jamal Abdunassir's - جمال عبدالناصر was conducted and published in 1980 ten years after the death of Nasser in 1970. The study discussed the speeches of Sadat also hold the same feature. The study was conducted and published in 1990 nine years after the famous assassination of Sadat in 1981. The same feature is also shared with a modern study which is going to be discussed below. 
$\mathrm{A} \mathrm{PhD}$ thesis of the speeches delivered during the war on Iraq was conducted. The data of the research was the speeches given by four political figures, who were in a way or another involved in that war and those figures are President George Bush, Prime Minister Tony Blair, President Saddam and the leader of Al-Qaeda Osama Bin Ldin. The study was conducted in 2007 after the regime of Saddam Hussain was removed from power. The data of the study covered many speeches given by these four figures during the war. The data contained eight speeches delivered by President Bush, seven for PM Blair, nine for President Hussain and six for Bin Ladin. The data was divided into Arabic and English data.

The author did not obtain a translation of the Arabic data represented in the speeches of President Hussain and Bin Ladin as one of the aims of the researcher was to compare the rhetorical tools used in the English data and the Arabic data, along with other main aims such as the concept of power and ideology as represented and as believed in by these four political figures. The methodology that the researcher used to approach his questions was to a far extent inspired by the framework and devices of discourse analysis put and suggested by Fairclough and Van Dijk.

Among the devises used to answer the questions of the research are Argument and Structure, Discursive strategies identification, Local and global meaning and formal structure. Each speaker's speeches were analyzed and discussed separately. The research did not target the speeches line by line or element by element as the study was qualitative not quantitative, so for making an argument the researcher would take excerpts from all the speeches and make an argument for how a certain device was used by the political figure his speeches are under investigation. The researcher was so successful in putting the reader very close to data under investigation by discussing and giving a background to the context of the speeches and the actors involved in those speeches. This study is like the first study discussed use different speeches of different figures as a data to be analyzed, however, it differs in that the figures are of different languages which are Arabic and English.

The researcher was able to reach some conclusions using the methodology she put together for this purpose. One of the similarities that the researcher found between the four political figures was that all four of them thought of the future and presented their expectations in regard to it. They tried to materialize and drill the potential threat that the enemy would bring about if not faced now rigorously. All of the political figures studied used this technique, for example President Bush and PM Blair talked about the mass destruction weapon of President Hussain and Bin Ladin and President Hussain talked about the Crusades and the Islamic historical battles (Balfaqeeh, 2007). This conclusion that the researcher was able to derive from her data implies that there is no specific technique that western politicians use under certain circumstances nor there are certain techniques that Arab politicians use under certain circumstances. All persuasion techniques may have an effect on humans regardless of their race or background.

All of the studies presented so far have been done and conducted at different times for different purposes and as mentioned before the studies around the notion of the Arab Spring and the speeches delivered during it were very few. One of the studies conducted and took 
speeches delivered during the Arab Spring as source of data will be discussed below.

This study was conducted by Maalej (2012). The data of this study was the last three speeches given by the ousted President of Tunisia President Ben Ali. The main aim of this paper was, among other things, to study the last three speeches with special reference to the person deixis used and the ideological uses of person deixis in political speeches. The researcher followed a multidisciplinary methodology by mingling the approaches and norms of CDA and the visions of cognitive- pragmatics. By using such methods the researcher was able to reach some conclusions. At the level of deixis a dramatic shifts of pronouns and pronouns configurations were noticed. These shifts were motivated by parallel events in the economic, political and social context. For example in his last speech or as the researcher called it "Ultimate speech", a shift in the relationship between Ben Ali and the addresses of his speeches were noted. The pronouns "I" and "You" in this speech outnumbered the same pronouns in the other two speeches. According to the researcher this quantitative shift suggest a shift in the relationship between the ousted President and the addresses. It is suggested by the researcher that in the first two speeches delivered by Ben Ali there was no thinking of the people of Tunisia as true interlocutors except of very few "I" occurrences, however, in the last speech the people of Tunisia were addressed with "you" which has the influence of carrying the addresses closer the deictic center in this speech than the other two delivered speeches (Maalej, 2012). What is interesting about this study is that it is one of the very few studies that took the speeches delivered during the notion of Arab Spring as a source of data. However, there is a similarity between this study and the other studies presented so far. This study was conducted in 2012 after the ousting of President Ben Ali, like most of the studies presented so far, which brings the question of why most studies take place after the meant figures are out of the office or dead back to the surface. Another interesting thing about this study is that it took a grammatical aspect of language and was able to derive patterns and conclusions out of it and explain them in light of context and what was going in Tunisia at that time, which means that certain grammatical uses could serve as an evidence when analyzing discourse and making judgments. Another thing that is obvious from the studies just presented is the large amount of different disciplines, methods and approaches that go into analyzing discourse. To analyze and answer certain questions that researchers might have in regard to certain texts they have to formulate approaches and methods suitable for analysis to get the best possible answers to their questions and this is a unique characteristic of discourse analysis.

One of the recent studies as well, however so unique in the angle it has chosen to tackle the topic of Arab spring is a study that discussed the revolution as seen by the Syrian regime and as seen by the rebels between March and November 2011. The title of the study was Discourses of a Revolution: Framing the Syrian Uprising by Emma Lundgren-Jörum, The author collected interviews, speeches delivered by President Assad and some reports that were posted on the website of the Syrian Arab News Agency (SANA). The views of the rebels were collected and analyzed using reports and interviews of some of the opposition's organizations, manly the Syrian National Council (SNC), which was established after the start of the revolution. The author used the collected speeches and interviews by these two 
antagonists, the regime and the opposition, to form a corpus through which he provided discussion on key areas such as why this revolution started and what is the part of each antagonist the revolution. The second key area was the views of the two antagonists in regard to the moving forward and how they anticipate things should develop toward ending this issue of armed unrest. The last area of discussion was the area of the future from the point of view of each antagonist. The author concluded that each party told a different story and held a different point of view about the revolution. It is asserted in the study that the regime stressed that the revolution is a conspiracy and that Syria is a victim to that conspiracy, where armed terrorists are killing civilians and security personnel indistinctively. It is concluded that the rebels' view of the matter revolves around the argument that the revolution is a domestic affair started and run by oppressed ordinary people. It is also concluded in the study that the views of the opposition's organizations are to a far extent unified and on the same track and that both the regime and the opposition, when it comes to the issue of minorities, concentrate on the Kurd minority and avoid the other minorities effectively.

When it comes to the method followed in this study it could be seen that to achieve the goals and aims of the study the author took excerpts from all the speeches and the interviews and analyzed the rhetorical devices used in them. However, it is clear that the rhetorical devices and their occurrence were not the main aim of the author, rather what was the main aim is what these devices account for generally, because none of the devices has been mentioned or referred to directly in the method or in the conclusion. It is mentioned in the start of the discussion of this study that this study is unique because of the angle it has tackled the topic of Arab spring from, another uniqueness of the study comes from the fact that this study is conducted about a regime that is still in power.

Another study that is conducted about a regime that is still in power is the study done by Jasim and Mustafa (2020) This study is concerned with manipulation in two political speeches; one in English delivered by the American President Donald J. Trump, while the other in Arabic delivered by the Iraqi President Barham Salih to be the study's data. The main aim of the study was to investigate the semantic and rhetorical devices utilized as manipulation strategies in the two speeches. This study draws on Van Dijk's ideological approach to Critical Discourse Analysis (CDA) of political discourse, and accordingly, it is adopted as a model. Results revealed that both speakers use lexicalization, a list of three, repetition, and citing as effective techniques in their two speeches to affect their recipients' minds. The study concluded that the ideological framework of "positive self-presentation" and "negative other-presentation" is the central umbrella under which manipulation can exist and work freely.

Three things could be noticed here and make this study unique. First this study was conducted about a president that is still in power. The second thing it showed that regardless of the cultural heritage and the differences in context, political leaders follow similar strategies of manipulation when giving their speeches. The third thing is that no matter how drastic or normal the situation is, Arab leaders will always warn people of the foreign interface and the ambiguous "they", who would prey on the country's assets and prosperity. All presidents their countries were affected by the notion o Arab spring used this technique as 
suggested by (Qabani, 2017) and (Qabani, 2021). It is seem that it is a common characteristic of the political speeches of the post-cocolonization era to warn people of a possible new cocolonization and to keep them in fear of it.

As seen in one of the recently published study, the use of the pronoun "they" in post-colonization Arabic political speeches is not the only common feature among them. It is suggested that there are similarities and common features among Arabic political speeches of different Arab countries such as intertextuality, repetition and the use of pronouns (Alduhaim, 2019).

\section{Conclusion}

Form this look at the history and studies done on Arabic political discourse some hypothesis and claims could be made in regard to the political discourse in Arabic. One of the first hypotheses is that in early Islamic ear there is a very apparent and close relationship between politics and religion. Almost all writers at that time strived to depict the ruler as the shadow of God on earth. Further, writers strived to find ways to convince people that whatever the ruler does is approved by God. This hypothesis is not peculiar to the early Islamic era. However, it could also be extended to the other discussed eras in this study. It is suggested that the political discourse or the speeches of the rulers in the different Arabic societies are looked at as one way speeches. These speeches are delivered with the purpose of emphasizing only facts and truths. They purposefully use a dazzling language that cannot be challenged or replaced to vanquish any possibility of criticism or questioning (H. Sharabi, 1992). This claim also might provide an answer to the question of why almost all of the studies in political discourse in the recent or the post-colonial era were conducted after the death or the toppling of the leaders their speeches were discussed or criticized. It is hypothesized that since the lonely purpose of the political speech in the Arabic society is to emphasize truths and unchallenged facts, it would be so difficult for an individuals to challenge publicly a speech based on the authority of the father, whose words, as suggested are backed up with holy scripts and derived from them. In summary, the words of the father cannot be criticized or as in Arabic (iتن / thtqd/-criticized, because the action of criticism is a synonym in Arabic to harsh words and backlashing (Mazid, 2014). It is suggested before that the studies that tackled speeches of Arab political figures were mostly done after the passing away or toppling of those political figures. However, this is not an absolute fact. We have presented two studies in which analysis and discussion of political speeches were done of regimes that are still in power. However, these two studies are an exception to the rule and the studies that were conducted about regimes that are still in power are scarcely out.

This review has discussed and listed the unprecedented political studies that discussed Arabic political discourse. There are other studies that were published and tackled some very important Arabic political discourse. They were not listed and discussed here not because they are unimportant, but because they take after some of the studies discussed here in terms of the questions and the methodology. Our study here is limited to the studies that were first in what they presented, made the norm and constructed realities about the Arabic political language. 


\section{Macrothink}

International Journal of Linguistics

ISSN 1948-5425

2022, Vol. 14, No. 1

The fact that studies of the Arabic political discourse are scarce still stands. We definitely need more and further studies that can enrich the field and give it its proper and desired attention. This study is going to hopefully shed more light on the Arabic political language, the history of it and the studies that done in regard to it. Due to the limitation of this study, as mentioned, many aspects of the Arabic political discourse could not be discussed such as the link between discourse and culture and many other societal aspects. This study will pave the way to such studies as it already provided the history and the features of the Arabic political language to the anticipated researchers.

\section{References}

Alduhaim, A. (2019). A Comparative Study of Political Discourse Features in English and Arabic. International Journal of English Linguistics, 9(6), 148-159.

Arendt, H. (1998). The Human Condition (2nd ed.). University of Chicago Press.

Balfaqeeh, M. (2007). A Critical Discourse Analysis of Arabic and English Political Speeches Delivered During the War in Iraq. (PhD), University of London.

Biber, D. (1994). An analytical framework for register studies. Sociolinguistic perspectives on register, 31-56.

Botcheesh, I. (2014). Justice Discourse in the Sultanic Literature. Arabic Center of Research and Policy Studies.

Crystal, D., \& Davy, D. (1988). Investigating English Style: Longman.

Davis, D. E., \& Go, J. (2009). Political Power and Social Theory. Emerald.

Eagleton, T. (2014). Ideology. Taylor \& Francis.

Eggins, S. (2004). An introduction to systemic functional linguistics. Continuum.

Esposito, J. L. (1998). Islam and politics. Syracuse University Press.

Fairclough, N., \& Fairclough, I. (2012). Political Discourse Analysis: A Method for Advanced Students. Routledge.

Falkoff, M., Miller, F., \& Dorfman, A. (2007). Poems from Guantanamo: The Detainees Speak. University of Iowa Press.

Goffman, E. (1981). Forms of Talk. University of Pennsylvania Press, Incorporated.

Gray, M. (2010). Conspiracy Theories in the Arab World: Sources and Politics. Taylor \& Francis.

Gumperz, J. J. (2009). The speech community. Linguistic anthropology: A reader, 1, 66.

Haas, M. L. (2018). The Arab spring: The hope and reality of the uprisings. Routledge.

Hasan, R. (2009). The place of context in a systemic functional model.

Hawting, G. R. (2002). The First Dynasty of Islam: The Umayyad Caliphate AD 661-750. 
Taylor \& Francis.

Hearst, D. (2011). Day Of Departure, Feb. 4, 2011: Crowd To Call For Mubarak To Resign. Retrieved from https://www.huffpost.com/entry/day-of-departure-feb-4_n_818398

Hymes, D. (1972). Toward ethnographies of communication: The analysis of communicative events. Language and Social Context, 21-44.

Jasim, R. M., \& Mustafa, S. S. (2020). A Semantic and Rhetorical Study of Manipulation in Two English and Arabic Political Speeches. Arab World English Journal, 11(4), 426-444.

Kraut, R. (2002). Aristotle: Political Philosophy. Oxford University Press.

Labov, W. (1972). Sociolinguistic Patterns. University of Pennsylvania Press, Incorporated.

Levinson, S. C. (1979). Activity types and language. Linguistics, 17(5-6), 365-400.

Longacre, R. E. (1976). An Anatomy of Speech Notions. Peter de Ridder Press.

Maalej, Z. A. (2012). The 'Jasmine Revolt' has made the 'Arab Spring': A critical discourse analysis of the last three political speeches of the ousted president of Tunisia. Discourse \& Society, 23(6), 679-700.

Marcuse, H. (2002). One-dimensional Man: Studies in the Ideology of Advanced Industrial Society. Routledge.

Marzūq, A. (1966). Alkhataba Alsiyasiay Fe Misr men alihtilal ela Elan Alhimayah [Political Oratory in Egypt from Occupation Till Proctorate Announcement]. The NAtional Center for Printing and Publishing.

Mazid, B. E. (2014). CDA and PDA Made Simple: Language, Ideology and Power in Politics and Media. Cambridge Scholars Publisher.

Meier, C. (1990). The Greek Discovery of Politics. Harvard University Press.

Mohammed, A. (1990). Alkhitab Alsadati:Tahleel Alhaqil Aloduoloji Lilkhitab Alsadait [Speech of Sadat: Ideological Feild Analysis of Sadat Speech]. Cairo: Alahali Book.

Nasr, M. (1981). Altasawor Alkawmi Alarabi Fe Fikr Jamal Abdunasser [Arabic Nationalisim Comprehension in Jamal Abdunasser's Thinking. Cairo Arabic Unity Stuides Center.

Qabani, A. (2017). Language, Power and the "Arab Spring”: Three Case Studies. (PhD Theoretical thesis), Macquaire University Macquaire University (mq:70648).

Qabani, A. (2021). Identity Negotiation in the Arab Spring Discourse: the Egyptian Case. Language, Discourse \& Society, 9(2(18)), 63-78.

Sacks, D., Murray, O., \& Brody, L. R. (2009). Encyclopedia of the Ancient Greek World. Facts On File, Incorporated. 


\section{Macrothink}

International Journal of Linguistics

ISSN 1948-5425 2022, Vol. 14, No. 1

Sacks, H., \& Jefferson, G. (1992). Lectures on Conversation. Blackwell.

Schegloff, E. A. (1972). Sequencing in conversational openings. Directions in sociolinguistics, 346-380.

Sharabi, H. (1992). Neopatriarchy. Oxford University Press.

Sharabi, H. (1992). Neopatriarchy: A Theory of Distorted Change in Arab Society. Oxford University Press.

Stephanous, A. Z. (2012). Political Islam, Citizenship, and Minorities: The Future of Arab Christians in the Islamic Middle East. UPA.

Suleiman, Y., Suleiman, P. M. A. S. Y., Tripp, C., \& Clancy-Smith, J. A. (2004). A War of Words: Language and Conflict in the Middle East. Cambridge University Press.

Tischler, H. L. (2010). Cengage Advantage Books: Introduction to Sociology. Wadsworth, Cengage Learning.

Valéry, P. (1943). Tel Quel: Libr. Gallimard.

Vysotsky, A. (2014). Russia and the Arab spring. Connections, 14(1), 41-64.

Whorf, B. L. (1956). The relation of habitual thought and behavior to language. na.

\section{Copyrights}

Copyright for this article is retained by the author(s), with first publication rights granted to the journal.

This is an open-access article distributed under the terms and conditions of the Creative Commons Attribution license (http://creativecommons.org/licenses/by/4.0/) 